\title{
A study on women's involvement and their training needs in rice cultivation in Chatra district of Jharkhand India
}

V.K. Pandey, R.K.Singh, D. Oraon, V.P. Rai, U.K. Singh, Z. Alam and R.P. Singh Ratan

See end of the Paper for authors' affiliation

Correspondence to :

V. K. Pandey

Krishi Vigyan Kendra (B.A.U.), Chatra (Ranchi) India

Email : vinod.bau@

rediffmail.com/

chatrakvk@gmail.com
-ABSTRACT : A study on women's involvement and their training needs in rice cultivation was studied Chatra district in five selected villages, one each from five selected blocks i.e. Kunda, Partappur, Simariya, Tandwa and Hunterganj covering 250 respondents. Results indicated that harvesting was the activity in which farm women were mostly involved followed by transplanting and weeding, seed selection and treatment, sowing and nursery raising and seed grain storage with weighted mean scores of 2.57, 2.56, 2.38, 2.25, 2.18, 1.96 and 1.37, respectively. Plant protection was rated first training need followed by seed and grain storage, land preparation, seed selection and treatment and sowing and nursery raising with weighted mean scores of 2.36, 2.24, 2.20, 2.08, 2.04 and 2.01, respectively.

- KEY WORDS : Training needs, Rice cultivation, Women's involvement

-HOW TO CITE THIS PAPER : Pandey, V.K.,Singh, R.K.,Oraon, D., Rai, V.P., Singh, U.K., Alam, Z. and Ratan, R.P. Singh (2018). A study on women's involvement and their training needs in rice cultivation in Chatra district of Jharkhand India. Internat. J. Agric. Engg., 11(1) : 153-155, DOI: 10.15740/HAS/IJAE/11.1/153-155. 